\title{
Role of taurine in the central nervous system
}

\author{
Jang-Yen $\mathrm{Wu}^{*}$, Howard Prentice \\ From $17^{\text {th }}$ International Meeting of Taurine \\ Fort Lauderdale, FL, USA. 14-19 December 2009
}

\begin{abstract}
Taurine demonstrates multiple cellular functions including a central role as a neurotransmitter, as a trophic factor in CNS development, in maintaining the structural integrity of the membrane, in regulating calcium transport and homeostasis, as an osmolyte, as a neuromodulator and as a neuroprotectant. The neurotransmitter properties of taurine are illustrated by its ability to elicit neuronal hyperpolarization, the presence of specific taurine synthesizing enzyme and receptors in the CNS and the presence of a taurine transporter system. Taurine exerts its neuroprotective functions against the glutamate induced excitotoxicity by reducing the glutamate-induced increase of intracellular calcium level, by shifting the ratio of $\mathrm{BCl}-2$ and Bad ratio in favor of cell survival and by reducing the ER stress. The presence of metabotropic taurine receptors which are negatively coupled to phospholipase C (PLC) signaling pathway through inhibitory $\mathrm{G}$ proteins is proposed, and the evidence supporting this notion is also presented.
\end{abstract}

\section{Introduction}

Taurine, 2-amino-ethanesulfonic acid, is one of the most abundant amino acids in mammals [1]. The physiological role of taurine has received considerable attention since the reports that cats fed a taurine deficient diet developed central retinal degeneration [2] and cardiomyopathy [3]. Now, taurine has been shown to be involved in many important physiological functions [for review, see [4]] e.g., as a trophic factor in the development of the CNS [5] and, for instance, kittens from the taurine-depleted mothers exhibit a delay in the migration of cells in the cerebellum and in the visual cortex [5]. It also serves in maintaining the structural integrity of the membrane [6], regulating calcium binding and transport $[7,8]$, as an osmolyte $[9,10]$, a neuromodulator [11], a neurotransmitter [12-18] and a neuroprotector against L-glutamate (LGlu)-induced neurotoxicity $[19,20]$. In this article, the role of taurine in the central nervous system (CNS) as a neurotransmitter, a neuro-protective agent and a potent regulator for intracellular calcium homeostasis will be reviewed.

\footnotetext{
* Correspondence: jwu@fau.edu

Charles E. Schmidt College of Biomedical Science, Florida Atlantic University, Boca Raton, FL 33431, USA

Full list of author information is available at the end of the article
}

\section{Taurine as a neurotransmitter}

In general, a substance can be accepted as a neurotransmitter if it has fulfilled the following set of criteria: firstly, the substance and/or its synthesizing enzyme has to be present in the suspected neuron, preferably it is concentrated at the nerve terminal; secondly, it is released upon stimulation in a calcium-dependent manner; thirdly, it elicits proper physiological response; fourthly, a specific receptor is present and fifthly, an inactivation mechanism is present to terminate the action of the suspected neurotransmitter. The following lines of evidence have supported the notion that taurine is a neurotransmitter in the mammalian CNS: 1 . The presence of a specific enzyme responsible for taurine biosynthesis in the brain, namely, cysteic/cysteine sulfinic acid decarboxylase (CAD/CSAD) which is distinctly different from the GABA-synthesizing enzyme, L-glutamate decarboxylase (GAD) was reported [21,22]. Immunocytochemical studies have revealed the localization of CAD/CSAD in the cell body, dendrite as well as in the nerve terminal [13][17][18][23][24-26]; 2. Release of taurine has been shown to be either calcium dependent or calcium independent [13]; 3. Taurine has been shown to elicit neuronal hyperpolarization presumably through its action by opening the chloride channels in the cerebellum [27] and in the hippocampus [14]; 4. The presence of a specific taurine receptor has been 
demonstrated. Previously we reported the presence of specific taurine receptors which have $K d$ in $n M$ range and are distinctly different from $\mathrm{GABA}_{\mathrm{A}}, \mathrm{GABA}_{\mathrm{B}}$ and glycine receptors since the agonists or antagonists of these receptors have little effect on the binding of taurine to taurine receptors [28]. Similar observations were recently reported by Frosini et al [29]; 5. The presence of a taurine transporter system for inactivation of its function has also been reported [30]. In fact, taurine transporters have been cloned [31] and taurine transporter knock-out transgenic mice have been established [32]. In summary, taurine has fulfilled most if not all of the criteria to be accepted as a neurotransmitter in the mammalian CNS.

\section{Regulation of intracellular calcium homeostasis}

It is known that the level of intracellular free calcium, $\left[\mathrm{Ca}^{2+}\right]_{\mathrm{i}}$, is maintained at sub-micromolar concentration by calcium sequestering into internal calcium storage pools e.g., mitochondria, endoplasmic reticulum (ER) as well as pumping out to the extracellular space by calcium-ATPase. When neurons are stimulated by glutamate, the $\left[\mathrm{Ca}^{2+}\right]_{\mathrm{I}}$ level is elevated due to influx of calcium from extracellular sources through various calcium channels including NMDA receptors, voltagegated calcium channels (VGCC) such as L-, N- and P/ Q-type, reverse mode of $\mathrm{Na}^{+} / \mathrm{Ca}^{2+}$ exchanger as well as release of calcium from the internal calcium storage pools. However, in the presence of taurine, glutamateinduced increase of $\left[\mathrm{Ca}^{2+}\right]_{\mathrm{i}}$ is markedly reduced as shown in Fig 1.

We [33] and El Idrissi \& Trenkner [20] reported that one of the pathways by which taurine reduced glutamateinduced elevation of $\left[\mathrm{Ca}^{2+}\right]_{\mathrm{i}}$ is through inhibition of $\mathrm{Ca}^{2+}$ influx via the reverse mode of $\mathrm{Na}^{+} / \mathrm{Ca}^{2+}$ exchanger. At the resting membrane potential, $\mathrm{Na}^{+} / \mathrm{Ca}^{2+}$ exchanger functions to move $\mathrm{Ca}^{2+}$ out of the cell. However, under depolarizing conditions such as under glutamate stimulation, it reverses its function to facilitate $\mathrm{Ca}^{2+}$ influx [34]. The effect of taurine on $\mathrm{Na}^{+} / \mathrm{Ca}^{2+}$ exchanger has been suggested to be in part due to in part its membrane stabilizing activity [35]. It has been shown that phospholipid Nmethylation is associated with a decrease in $\mathrm{Na}^{+} / \mathrm{Ca}^{2+}$ exchanger activity [36]. Hence, taurine-mediated reductions in phospholipid $\mathrm{N}$-methyltransferase activity enhance efflux of $\mathrm{Ca}^{2+}$ through the $\mathrm{Na}^{+} / \mathrm{Ca}^{2+}$ exchanger and lower tissue $\mathrm{Ca}^{2+}$ content. Taurine also promotes $\mathrm{Ca}^{2+}$ efflux via the $\mathrm{Na}^{+} / \mathrm{Ca}^{2+}$ exchanger by increasing $\left[\mathrm{Ca}^{2+}\right]_{\mathrm{i}}$ in the vicinity of the exchanger. [35]. In addition to $\mathrm{Na}^{+} / \mathrm{Ca}^{2+}$ exchanger, taurine also inhibits the release of $\mathrm{Ca}^{2+}$ from internal pools [37] as well as inhibits various voltage-gated calcium channels (VGCC) such as L-, N- and P/Q-type [38]. Although osmotic stress and taurine treatment were reported to affect various channels such as the $\mathrm{Na}^{+} / \mathrm{Ca}^{2+}$

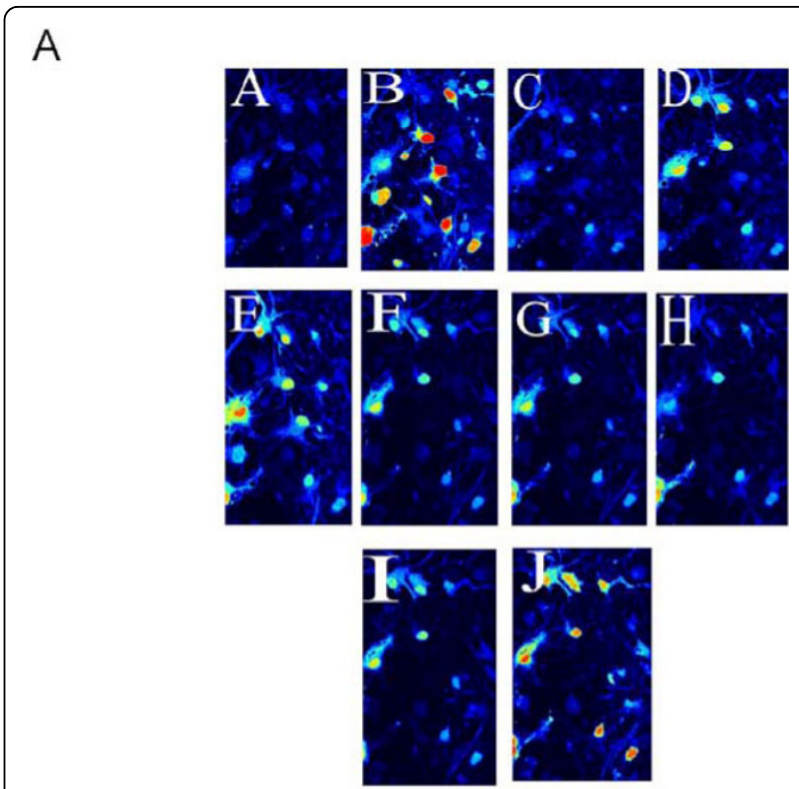

B

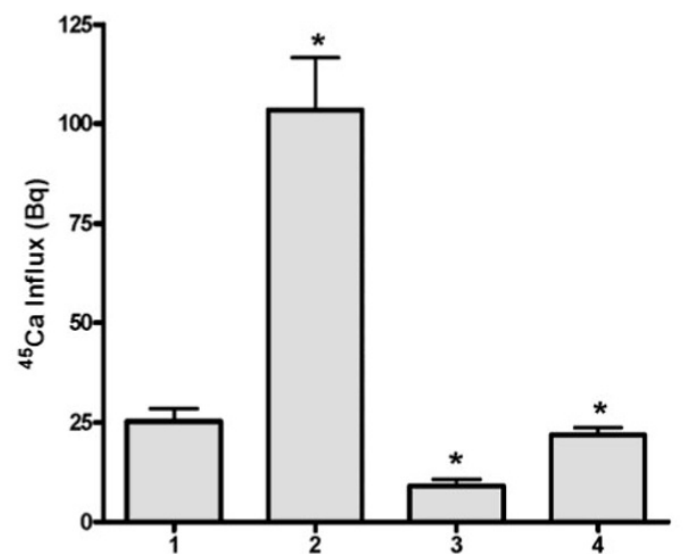

Figure 1 Effect of taurine on glutamate induced $\left[\mathrm{Ca}^{2+}\right]_{i}$ accumulation (A) confocal study - A. Baseline; B \& J. Glutamate; C, F \& I. After washing; D. Nifedipine; E. Nifedipine plus glutamate; G. Taurine; $\mathrm{H}$. Taurine plus glutamate. Color coding indicates $\left[\mathrm{Ca}^{2+}\right]_{\mathrm{i}}$, red being the highest and blue the lowest. (B). Accumulation of ${ }^{45} \mathrm{Ca}^{2+}$ influx - 1. Control; 2. Glutamate; 3. Glutamate plus $25 \mathrm{mM}$ taurine; 4 . Glutamate plus $5 \mathrm{mM}$ taurine.

exchanger, the ATP-sensitive $\mathrm{K}^{+}$channel, the L-type VGCC and the fast $\mathrm{Na}^{+}$channel [39], we believe that in neuronal systems, the effect of taurine on various calcium channels is likely due to a combination of counteraction of glutamate-induced depolarization by taurine as well as receptor-mediated G-protein coupled events. This notion is supported by the following observations: First of all, recently we have shown that when glutamate-induced membrane depolarization is abolished by taurine as measured by voltage-sensitive dye, the VGCC activity is also suppressed [38]. Secondly, Kaczmarek [40] reported that exposure of isolated bag cell neurons to activators of 
A

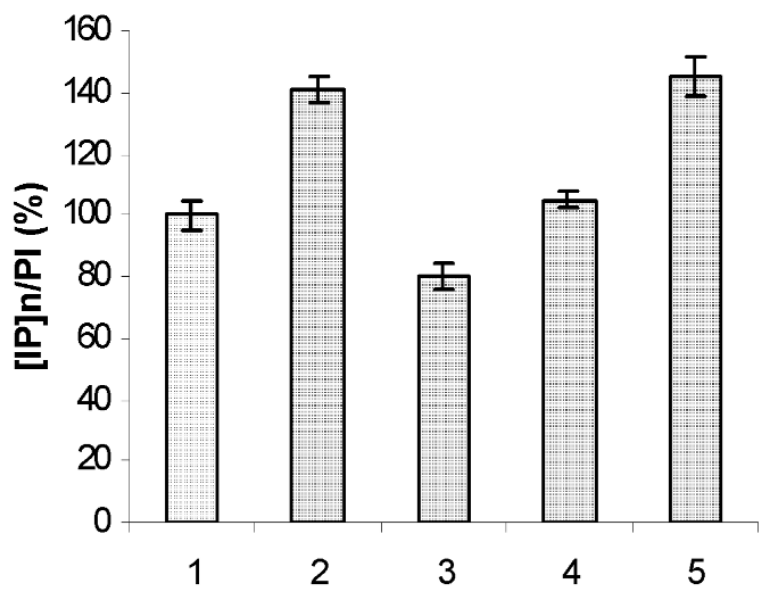

B

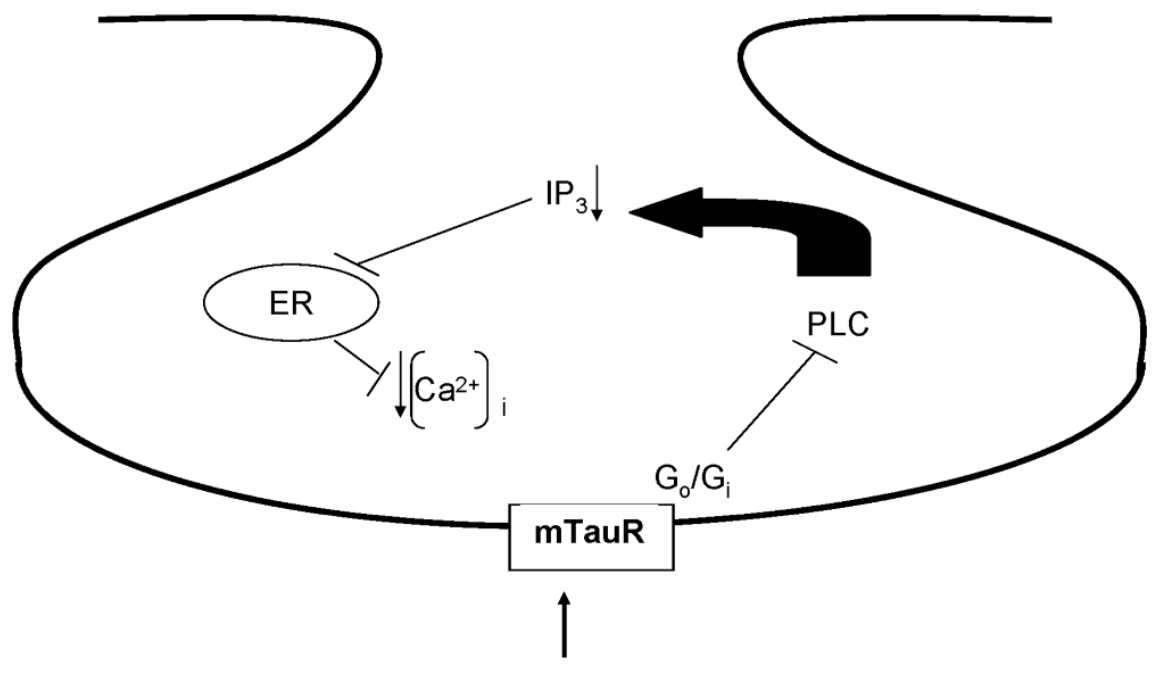

Tau

Figure 2 A. Effect of taurine on PLC activity; B. A proposed model for the mode of action of taurine on the IP3 pathway. A. Effect of taurine on PLC activity. 1). Control, 2). $0.25 \mathrm{mM}$ Glu, 3). $25 \mathrm{mM}$ taurine, 4). $25 \mathrm{mM}$ taurine plus $0.25 \mathrm{mM}$ Glu, 5). $10 \mu \mathrm{M}$ carbachol. The error bar indicates the standard deviation with $\mathrm{N}=3$. Briefly, ${ }^{3} \mathrm{H}$-inositol was used as precursor for $\left[{ }^{3} \mathrm{H}\right]$-phosphoinositides (PI). Hydrolysis of [PI] to inositol phosphates, [IP] $]_{n}$, is an index of PLC activity. The experiments were performed as described previously [45]. Primary neuronal cultures in $35 \mathrm{~mm}$ dishes were first labeled with $8 \mu \mathrm{Ci}$ of $\left[{ }^{3} \mathrm{H}, \mathrm{U}\right]$-inositol for 24 hours. The cells were washed with fresh medium containing $2 \mathrm{mM} \mathrm{LiCl}$ (to prevent $\mathrm{IP}_{3}$ dephosphorylation) and exposed to either Glu, taurine, or carbachol (a muscarinic cholinergic receptor agonist known to stimulate PLC), as indicated. Phosphoinositides, $[\mathrm{PI}]$, and inositol phosphates, $[\mathrm{IP}]_{\mathrm{n}}$, were determined from the organic phase and aqueous phase, respectively as described [45]. The results are expressed as the ratio of $[\mathrm{IP}]_{\mathrm{n}}$ to $[\mathrm{PI}]$. The results show that taurine reduces the production of basal level of $[\mathrm{IP}]_{\mathrm{n}}$ by $20 \%$ (column 3) and Glu-stimulated increase of $[\mathrm{IP}]_{\mathrm{n}}$ production by $40 \%$ (column 4). This coupled with the above results suggest that taurine may reduce the basal level or Glu-induced increase of poly-PI turnover through its inhibitory effect on PLC via inhibitory G-proteins e.g. $G_{i} / G_{0}-$ like proteins. B. A proposed model for the mode of action of taurine on the IP3 pathway. Diagram illustrating that taurine's action on taurine receptors results in an inhibition of PLC activity causing a reduction in IP3 formation thus reducing IP3 mediated release of calcium from internal stores. 


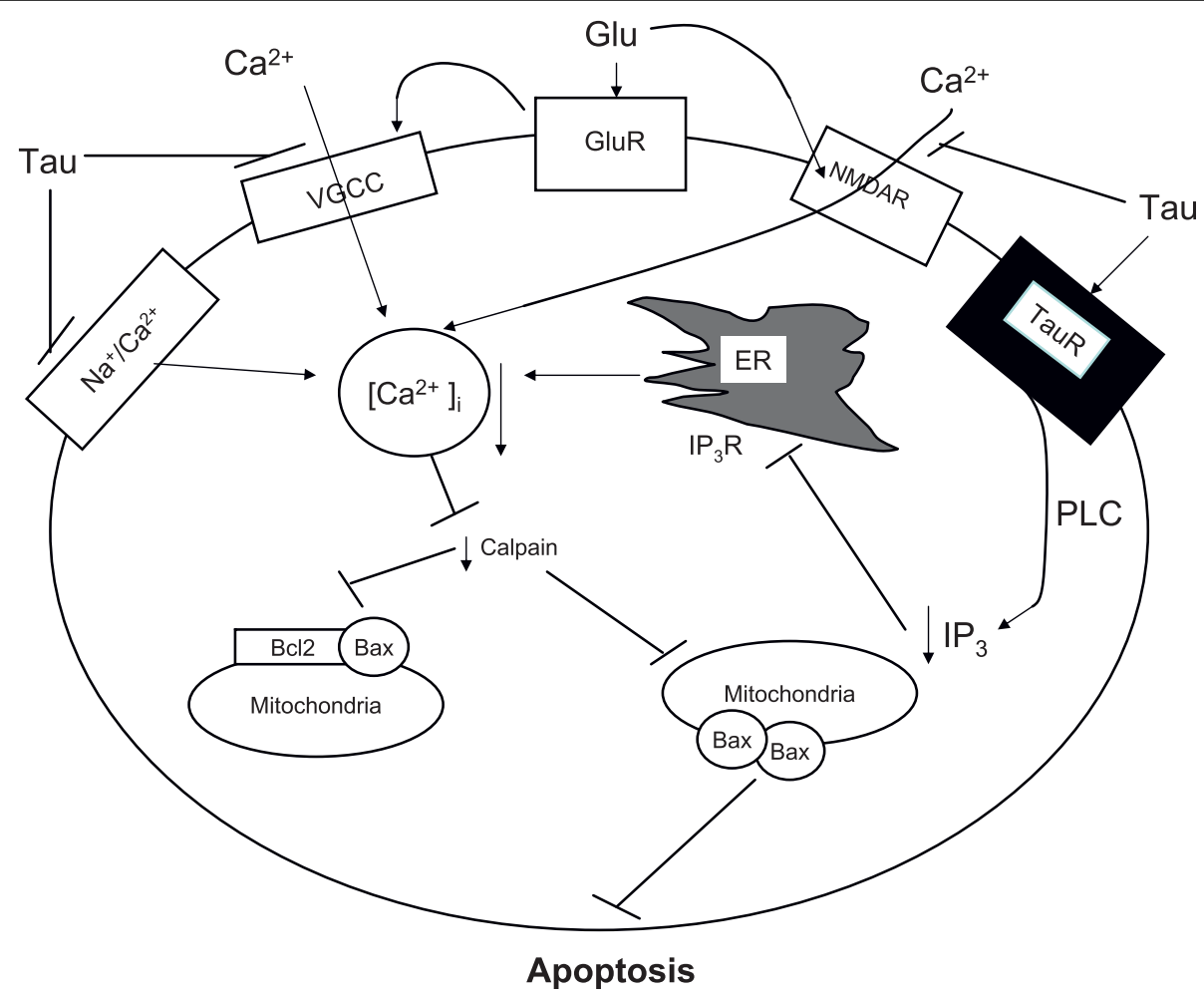

Figure 3 A model depicting the pathway that taurine exerts its function against glutamate-induced apoptosis. Taurine's neuroprotective functions are due to its role in reducing intracellular free calcium concentration and its antioxidative stress capacity. Taurine can shift the ratio of anti-apoptotic Bcl-2 protein and pro-apoptotic Bax protein towards cell survival. As shown in the diagram taurine inhibits glutamate-induced activation of calcium and the subsequent heterodimerization of $\mathrm{BCl}-2$ and Bax protein resulting in the apoptosis cascade.

protein kinase $\mathrm{C}$ caused an increase in the amplitude of voltage-dependent calcium current. Since taurine can prevent protein phosphorylation, such as of its own synthesizing enzyme, CSAD [41], it is reasonable to believe that taurine also can prevent glutamate-induced VGCC activation by inhibiting phosphorylation of these channel proteins. Thirdly, previously we reported the presence of specific taurine receptors which have $\mathrm{Kd}$ in $\mathrm{nM}$ range and are distinctly different from $\mathrm{GABA}_{\mathrm{A}}, \mathrm{GABA}_{\mathrm{B}}$, glycine and glutamate receptors since the agonists or antagonists of these receptors have little effect on the binding of taurine to taurine receptors [42]. Similar observations were also reported by Frosini et al [29]. Furthermore, the binding of taurine to taurine receptors is inhibited by GTP or its non-hydrolyzable GTP analog, $[\gamma-S]-G T P$, in a dosedependent manner [43]. It is believed that binding of GTP to the $\alpha$-subunit of G-protein promotes the dissociation of G-protein from the receptors resulting in the conversion of receptors back to their low affinity conformation. Fourthly, the inhibitory effect of GTP on taurine receptor binding disappeared once G-proteins were removed from the receptors by treating the membranes with a low concentration of Triton X-100 [43]. Fifthly, Glu-induced elevation of $\left[\mathrm{Ca}^{2+}\right]_{i}$ in the absence of extracellular $\mathrm{Ca}^{2+}$ is inhibited by taurine suggesting that taurine inhibits the Glu-induced release of $\mathrm{Ca}^{2+}$ from the internal pools [37]. It is of interest that $\mathrm{GABA}_{\mathrm{B}}$ receptor agonists such as baclofen were reported to inhibit a variety of VGCCs including $\mathrm{L}-$, $\mathrm{N}$ - and $\mathrm{P} / \mathrm{Q}$-type VGCC through $\mathrm{GABA}_{\mathrm{B}}$ receptor-coupled inhibitory G-proteins, $G_{o}$ and $G_{i}[44]$. Here we propose that similar to the $G_{A B A}$ receptors, when the metabotropic taurine receptors (mTauR) are activated by taurine, the coupled inhibitory G-proteins e.g. $G_{o} / G_{i}$ are then activated resulting in inhibition of VGCCs. Furthermore, we propose that $\mathrm{mTauR}$ are negatively coupled to phospholipase C (PLC) through inhibitory Gproteins, e.g. $G_{o} / G_{i}$ analogous to the $G_{A B A}$ receptors which are negatively coupled to adenylyl cyclase through inhibitory G-proteins [44]. Activation of taurine receptors by taurine would lead to inhibition of PLC activity (Fig 2), resulting in reduction in $\mathrm{IP}_{3}$ formation and hence $\mathrm{IP}_{3}$-mediated release of $\mathrm{Ca}^{2+}$ from the internal pools.

\section{Taurine as a neuroprotective agent}

One important function of taurine is its neuro-protective function. We $[19,33]$ as well as others [20] have shown that taurine can effectively prevent glutamate-induced neuronal injury in cultured neurons. In addition, we have 
also demonstrated that taurine can protect against $\mathrm{H}_{2} \mathrm{O}_{2}$ induced cell injury in $\mathrm{PC} 12$ cell cultures by reducing $\mathrm{H}_{2} \mathrm{O}_{2}$-induced ER stress (Pan et al 2010, in this issue). It is generally believed that taurine's neuroprotective functions are due to its role in reducing intracellular free $\mathrm{Ca}^{2+}$ concentration, $\left[\mathrm{Ca}^{2+}\right]_{i}$, and its anti-oxidative stress capacity $[33,35]$. We have recently shown that taurine can shift the ratio of the anti-apoptotic protein, Bcl-2 and the pro-apoptotic protein, Bax, in favor of cell survival [38]. In addition, we have also demonstrated that glutamate-induced activation of calpain is inhibited by taurine resulting in decrease of formation of hetero-dimers of $\mathrm{Bcl}-2$ and Bax and the subsequent release of cytochrome $\mathrm{C}$ and the apoptosis cascade [38]. The sequence of events by which that taurine exerts its neuroprotective function can be summarized as follows:

1. Taurine reduces glutamate-induced elevation of $\left[\mathrm{Ca}^{2+}\right]_{\mathrm{I}}$ by inhibiting calcium influx from various calcium channels including the reverse mode of $\mathrm{Na}^{+} / \mathrm{Ca}^{2+}$ exchanger, various voltage-gated calcium channels (VGCC) such as L-, N- and P/Q-type, and glutamate NMDA receptors.

2. Taurine inhibits phosphorylation of VGCC resulting in decrease of calcium influx 3 . Taurine also reduces the release of calcium from the internal storage pools presumably due to inhibition of phospholipase C.

3. Taurine inhibits glutamate-induced activation of calpain and the subsequent hetero-dimerization of $\mathrm{Bcl}-2$ and Bax protein resulting in inhibition of release of cytochrome $\mathrm{C}$ and the apoptosis cascade (Fig 3).

\section{Acknowledgements \\ This article has been published as part as part of Journal of Biomedical Science Volume 17 Supplement 1, 2010: Proceedings of the 17th International Meeting of Taurine. The full contents of the supplement are available online at http://www.jbiomedsci.com/supplements/17/S1.}

\section{Competing interests}

The authors declare that they have no competing interests.

Published: 24 August 2010

\section{References}

1. Jacobsen JG, Smith LH: Biochemistry and physiology of taurine and taurine derivatives. Physiol Rev 1968, 48:424-511.

2. Hayes KC, Carey RE, Schmidt SY: Retinal degeneration associated with taurine deficiency in the cat. Science 1975, 188:949-951.

3. Pion PD, Kittleson MD, Rogers QR, Morris JG: Myocardial failure in cats associated with low plasma taurine: A reversible cardiomyopathy. Science 1987, 237:764-768.

4. Huxtable RJ: Expanding the circle 1975-1999: sulfur biochemistry and insights on the biological functions of taurine. Adv Exp Med Biol. 2000, 483:1-25.

5. Sturman JA: Taurine in development. Physiol Rev 1993, 73:119-147.

6. Moran J, Salazar P, Pasantes-Morales H: Effect of tocopherol and taurine on membrane fluidity of retinal rod outer segments. Experimental Eye Research 1988, 45:769-776.

7. Lazarewicz JW, Noremberg K, Lehmann A, Hamberger A: Effects of taurine on calcium binding and accumulation in rabbit hippocampal and cortical synaptosomes. Neurochem Int 1985, 7:421-428.
8. Lombardini JB: Effects of taurine on calcium ion uptake and protein phosphorylation in rat retinal membrane preparations. J Neurochem $1985,45: 268-275$.

9. Solia JM, Herranz AS, Herreras O, Lerma J, Del Rio RM: Does taurine act as an osmoregulatory substance in the rat brain. Neurosci Lett 1988, 91:53-58.

10. Wade JV, Olson JP, Samson FE, Nelson SR, Pazdernik TL: A possible role for taurine in osmoregulation within the brain. J Neurochem 1988, 51:740-745.

11. Kuriyama K: Taurine as a neuromodulator. Fed Proc 1980, 39:2680-2684.

12. Okamoto K, Kimura H, Sakai Y: Evidence for taurine as an inhibitory neurotransmitter in cerebellar stellate interneurons: Selective antagonism by TAG (6-aminomethyl-3-methyl-4H,1,2,4-benzothiadiazine1,1-dioxide). Brain Res 1983, 265(1):163-168.

13. Lin C-T, Su YT, Song G-X, Wu J-Y: Is taurine a neurotransmitter in rabbit retina? Brain Res 1985, 337:293-298.

14. Taber TC, Lin C-T, Song G-X, Thalman RH, Wu JY: Taurine in the rat hippocampus-localization and postsynaptic action. Brain Res 1986, 386:113-121.

15. Cunningham R, Miller RF: Taurine: Its selective action on neuronal pathways in the rabbit retina. Brain Res 1976, 117:341-345.

16. Mandel P, Pasantes-Morales H, Urban PF: Taurine, a putative transmitter in retina. Transmitters in the Visual Process Oxford: Pergamon, OxfordBontig SL. 1976, 89-105.

17. Lin C-T, Li H-Z, Wu J-Y: Immunocytochemical localization of L-glutamate decarboxylase, gamma aminobutyric acid transaminase, cysteine-sulfinic acid decarboxylase, aspartate aminotransferase and somatostatin in rat retina. Brain Res 1983, 270:273-283.

18. Lin C-T, Song G-X, Wu J-Y: Ultrastructural demonstration of L-glutamate decarboxylase and cysteinesulfinic acid decarboxylase in rat retina by immunocytochemistry. Brain Res 1985, 331:71-80.

19. Tang XW, Deupree DL, Sun Y, Wu J-Y: Biphasic effect of taurine on excitatory amino acid-induced neurotoxicity. Taurine: Basic and Clinical Aspects New York: Plenum Publishing Co.R. J. Huxtable RJ, Azuma J, Nakagawa M, Kuriyama K, Bala A. 1996, 499-506.

20. El Edrissi A, Trenkner E: Growth factors and taurine protect against excitotoxicity by stabilizing calcium homeostasis and energy metabolism. J Neurosci 1999, 19:9459-9468.

21. Wu J-Y, Moss LG, Chen MS: Tissue and regional distribution of cysteic acid decarboxylase in bovine brain. A new assay method. Neurochem Res 1979, 4:201-212.

22. Wu J-Y: Purification and characterization of cysteic/cysteine sulfinic acids decarboxylase and L-glutamate decarboxylase in bovine brain. Proc Natl Acad Sci USA 1982, 79:4270-4274.

23. Chan-Palay V, Lin CT, Palay S, Yamamoto M, Wu J-Y: Taurine in the mammalian cerebellum: Demonstration by autoradiography with $\left[{ }^{3} \mathrm{H}\right]$ taurine and immunocytochemistry with antibodies against the taurinesynthesizing enzyme, cysteine-sulfinic acid decarboxylase. Proc Natl Acad Sci USA 1982, 79:2695-2699.

24. Chan-Palay V, Palay SL, Li C, Wu J-Y: Sagittal cerebellar micro-bands of taurine neurons: Immunocytochemical demonstration by using antibodies against the taurine synthesizing enzyme cysteine sulfinic acid decarboxylase. Proc Natl Acad Sci USA 1982, 79:4221-4225.

25. Magnusson KR, Madl JE, Clements JR, Wu J-Y, Larson AA, Beitz AJ: Colocalization of taurine- and cysteine sulfinic acid decarboxylase-like immunoreactivity in the cerebellum of the rat with the use of a novel monoclonal antibody against taurine. J Neurosci 1988, 8(12):4551-4564.

26. Magnusson KR, Clements JR, Wu J-Y, Beitz AJ: Co-localization of taurineand cysteine sulfinic acid decarboxylase-like immunoreactivity in the hippocampus of the rat. Synapse 1989, 4:55-69.

27. Okamoto K, Kimura H, Sakai Y: Taurine-induced increase of the Clconductance of cerebellar Purkinje cell dendrites in vitro. Brain Res 1983, 259(2):319-323.

28. Wu J-Y, Tang XW, Tsai WH: Taurine receptor: kinetic analysis and pharmacological studies. Adv Exp Med Biol 1992, 315:263-268.

29. Frosini M, Sesti C, Saponara S, Ricci L, Valoti M, Palmi M, Machetti F, Sgaragli $G$ : A specific taurine recognition site in the rabbit brain is responsible for taurine effects on thermoregulation. Br J Pharmacol 2003, 139:487-494 
30. Chesney RW, Zelikovic I, Jones DP, Budreau A, Jolly K: The renal transport of taurine and the regulation of renal sodium-chloride-dependent transporter activity. Pediatr Nephrol 1990, 4(4):399-407.

31. Han X, Budreau AM, Chesney RW: Molecular cloning and functional expression of an LLC-PK1 cell taurine transporter that is adaptively regulated by taurine. Adv Exp Med Biol 1998, 442:261-268.

32. Warskulat U, Borsch E, Reinehr R, Heller-Stilb B, Mönnighoff I, Buchczyk D, Donner M, Flögel U, Kappert G, Soboll S, Beer S, Pfeffer K, Marschall HU, Gabrielsen M, Amiry-Moghaddam M, Ottersen OP, Dienes HP, Häussinger D: Chronic liver disease is triggered by taurine transporter knockout in the mouse. FASEB J 2006, 20(3):574-576.

33. Chen WQ, Nguyen M, Carr J, Lee YJ, Jin H, Foos T, Hsu CC, Davis KM, Schloss JV, Wu J-Y: Role of taurine in regulation of intracellular calcium level and neuroprotective function in cultured neurons. J Neurosci Res 2001, 66:612-619.

34. Takuma K, Matsuda T, Hashimoto $H$, Asano S, Baba A: Cultured rat astrocytes possess $\mathrm{Na}^{+}-\mathrm{Ca}^{2+}$ exchanger. Glia 1994, 12:336-342.

35. Schaffer S, Azuma J, Takahashi K, Mozaffari M: Why is taurine cytoprotective? Taurine 5 London: Kluwer Academic/Plenum PublishersLombardini J B, Schaffer S, Azuma J. 2003, 307-321.

36. Hamaguchi T, Azuma J, Schaffer S: Interaction of taurine with methionine: inhibition of myocardial phospholipids methyltransferase. J Cardiovasc Pharmacol 1991, 18:224-230.

37. Chen WQ: Mode of action of taurine. Ph.D. dissertation University of Kansas 2000.

38. Leon $\mathrm{R}$, Wu H, Jin Y, Wei J, Buddhala C, Prentice $H$, Wu JY: Protective function of taurine in glutamate-induced apoptosis in cultured neurons. J Neurosci Res 2009, 87(5):1185-1194.

39. Schaffer S, Takahashi K, Azuma J: Role of osmoregulation in the actions of taurine. Amino Acids 2000, 19:527-546.

40. Kaczmarek LK: Phorbol esters, protein phosphorylation and the regulation of neuronal ion channels. J Exp Biol 1986, 124:375-392.

41. Tang XW, Hsu CC, Schloss JV, Faiman MD, Wu E, Yang C-Y, Wu J-Y: Protein phosphorylation and taurine biosynthesis in vivo and in vitro. J Neuroscience 1997, 17:6947-6951.

42. Wu J-Y, Tang XW, Tsai WH: Taurine receptor: Kinetic analysis and pharmacological studies. Taurine: Nutritional Value and Mechanisms of Action New York: Plenum Publishing Co.Lombardini JB, Schaffer SW, Azuma J. 1992, 263-268

43. Foos TM, Wu J-Y: The role of taurine in the central nervous system and the modulation of intracellular calcium homeostasis. Neurochem Res 2002, 27:21-26.

44. Kaupmann K, Huggel K, Heid J, Flor PJ, Bischoff S, Mickel SJ, McMaster G, Angst $C$, Bittiger $H$, Froestl $W$, Bettler B: Expression cloning of $G_{A B A}$ receptors undercovers similarity to metabotropic glutamate receptors. Nature 1997, 386:239-246.

45. Lee YY, Deupree DL, Chen SC, Kao LS, Wu J-Y: Role of $\mathrm{Ca}^{2+}$ in AMPA mediated poly phosphoinositides turnover in primary neuronal cultures. J Neurochem 1994, 62:2325-2332.

doi:10.1186/1423-0127-17-S1-S1

Cite this article as: $\mathrm{Wu}$ and Prentice: Role of taurine in the central

nervous system. Journal of Biomedical Science 2010 17(Suppl 1):S1.

\section{Submit your next manuscript to BioMed Central and take full advantage of:}

- Convenient online submission

- Thorough peer review

- No space constraints or color figure charges

- Immediate publication on acceptance

- Inclusion in PubMed, CAS, Scopus and Google Scholar

- Research which is freely available for redistribution

Submit your manuscript at www.biomedcentral.com/submit
Biomed Central 